\title{
Sais solúveis e eflorescência em blocos cerâmicos e outros materiais de construção - revisão
}

\author{
(Soluble salts and efflorescence of ceramic bricks and \\ other building materials - review)
}

\author{
R. R. Menezes ${ }^{1}$, H. S. Ferreira ${ }^{2}$, G. A. Neves ${ }^{3}$, H. C. Ferreira ${ }^{3}$ \\ ${ }^{1}$ CPGCEM, Laboratório de Síntese e Processamento de Materiais Cerâmicos - LaSP \\ Universidade Federal de S. Carlos, S. Carlos, SP \\ ${ }^{2}$ Departamento de Educação, Universidade Rural de Pernambuco, Recife, PE \\ ${ }^{3}$ Departamento de Engenharia de Materiais, Centro de Ciências e Tecnologia, \\ Universidade Federal de Campina Grande, Campina Grande, PB \\ tel: 0XX-083-3101182, fax: 0XX-083-3101178 \\ heber@dema.ufcg.edu.br
}

\begin{abstract}
Resumo
Eflorescências são depósitos salinos que se formam na superfície de materiais cerâmicos, resultantes da migração e posterior evaporação de soluções aquosas salinizadas. As eflorescências trazem em si um problema mais de ordem estética do que estrutural, no entanto, por se tratar de um fenômeno complexo e com reflexos econômicos preocupa fabricantes e construtores. Os sais solúveis que dão origem às eflorescências podem ter várias origens, dentre elas as matérias-primas, os materiais de construção, a água existente no subsolo, etc. Assim, este trabalho tem por objetivo o estudo dos sais solúveis e eflorescências em materiais de construção cerâmicos e não cerâmicos, com ênfase nos trabalhos experimentais que foram recentemente desenvolvidos na Universidade Federal de Campina Grande, PB. Foram utilizadas amostras de argilas, tijolos, britas, areias e massames oriundas de várias regiões do Estado da Paraíba. A quantidade de sais solúveis nos materiais foi determinada utilizando-se a condutividade elétrica de seus extratos. Os ensaios de eflorescência foram conduzidos segundo a metodologia da ASTM. Pode-se observar que não há uma correlação bem definida entre o teor de sais solúveis das matérias-primas e o nível de eflorescência das peças cerâmicas. O teor de $0,025 \%$ de sais solúveis nos corpos cerâmicos aparenta ser um limite adequado para avaliar a aptidão, ou não, das peças para apresentarem eflorescências.
\end{abstract}

Palavras-chave: eflorescência, tijolos, argilas, matérias de construção.

\begin{abstract}
The deposition of salts on the surface of ceramic materials is called efflorescence. It is resulted from the migration and evaporation of aqueous saline solutions. The efflorescence is basically an aesthetic problem, but due to be a complex phenomenon with economical consequences it worries manufactures and building constructors. Raw materials, building materials, subsoil water, can be the source of soluble salts, which generate the efflorescence. This work is based on studies recently developed at the Federal University of Campina Grande, and has as aim analyze the soluble salts and efflorescence characteristics of ceramic and non-ceramic building materials. Samples of clays, bricks, and other building materials, from several parts from the State of Paraiba, were used in the study. The amount of soluble salts in the materials was determined using the electrical conductivity of its extracts. The efflorescence test was conducted according to the ASTM methodology. Based on the results was not observed a well-defined correlation between the amount of soluble salts of the raw materials and the efflorescence level. The content of $0.025 \%$ of soluble salts is a limit that offers a good indication of the materials susceptibility to efflorescence.
\end{abstract}

Keywords: efflorescence, bricks, clays, building materials.

\section{INTRODUÇÃO}

Os solos salinizados são os que apresentam uma maior concentração de saís solúveis ou de sódio trocável ou de ambos. Os sais solúveis do solo contêm principalmente os cátions sódio, cálcio e magnésio e os ânions cloretos e sulfatos e, em menor quantidade, ocorrem potássio, bicarbonatos e carbonatos. Geralmente $98 \%$ dos sais solúveis dos solos são formados por esses íons [1]. Pesquisas [2] evidenciam que a salinização dos solos ocorre devido às condições climáticas desfavoráveis, como elevada evaporação, baixa infiltração, ventos contínuos e baixa precipitação, o que explica a 
existência de maior concentração de sais nas regiões áridas e semi-áridas.

Os sais presentes no solo e/ou nos materiais utilizados na construção civil podem afetar as alvenarias e concretos, pela sua deposição na região interior ou exterior das construções. A formação de depósitos de sais em alvenarias e concretos ocorre pela cristalização dos sais das soluções aquosas, cuja saturação foi atingida em conseqüência da evaporação do solvente.

A solução aquosa é formada no interior da peça cerâmica pelo contato entre a água e sais solúveis presentes no material, ou é oriunda de fontes externas e movimenta-se de uma parte a outra da estrutura através da rede capilar do material. Assim, as condições necessárias para que ocorra a formação desses depósitos em alvenarias e concretos são a coexistência de: água, sais solúveis em água e condições ambientais e de estrutura que proporcionem a percolação e evaporação da água [3]. Se um destes três itens deixar de existir, não é possível a formação de depósitos de sais.

A evaporação da solução aquosa de sais pode ocorrer na superfície ou em regiões próximas a esta, apenas quando existe um gradiente de umidade entre a atmosfera ambiente e o material que favoreça este fenômeno. Entretanto, em ambientes de elevada umidade como porões, ou em presença de sais deliqüescentes (difícil secagem), os sais não chegarão a se cristalizar, depositando-se como um "gel", cuja viscosidade depende da composição e concentração da solução [4].

Por definição tem-se que os véus (do Espanhol "velos" e do Inglês "scum") são depósitos salinos que se formam em argilas ou em peças "cruas", pela ação da água como agente mobilizador dos sais solúveis. Florescências são depósitos salinos que se formam nas peças cerâmicas queimadas, sendo também a água o agente mobilizador dos sais solúveis. As florescências são atividades patológicas que se produzem nas peças cerâmicas mediante o estímulo de agentes externos [5].

Os véus podem ser classificados como véus de secagem, de secador e de forno. Os véus de secagem se formam durante a secagem ao ar livre de argilas ou peças cruas. A secagem, neste caso se produz pela ação do ar "limpo", natural. Véus de secador se formam nas peças por ação de ar industrial - possivelmente contaminado (principalmente com gases sulfurosos). Os véus de secador, formados na superfície das peças, se consolidam no forno por ação de diversas reações e se transformam no que se chamam, véus de forno. Ressaltando que um mesmo véu de secador pode dá origem a distintos véus de forno, de acordo com a atmosfera e os ciclos térmicos utilizados na queima $[5,6]$.

As florescências podem ser divididas em dois grandes grupos: subflorescências (criptoflorescências) e eflorescências. As subflorescências são florescências não visíveis, porque os depósitos salinos se formaram sob a superfície da peça, enquanto que nas eflorescências os depósitos salinos se formam na superfície dos produtos cerâmicos. A cristalização de sais na superfície das peças cerâmicas não produz esforços mecânicos importantes.
Ao contrário, quando a cristalização se dá no interior do material, nos poros e rede capilar, podem ser produzidos esforços mecânicos consideráveis. Assim, as eflorescências causam degradação microestrutural apenas nas zonas próximas a superfície, bem como degradação estética no produto cerâmico. Os danos na aparência das construções intensificam-se quando há um contraste de cor entre os depósitos de sais e a alvenaria [7]. Enquanto que as subflorescências podem causar sérios danos a durabilidade e resistência das peças [5].

Vários estudos tentaram correlacionar o teor de sais nas matérias-primas e nos produtos cerâmicos com sua aptidão a eflorescência. No entanto, poucos lograram êxito em encontrar alguma correlação entre o teor de sais nas matériasprimas e nos produtos e o seu "grau" de eflorescência. O que é esperado, já que, a eflorescência, ou não, de uma peça cerâmica está intimamente associada às características de processamento e das condições climáticas onde é utilizada. No entanto, esses estudos observaram haver certa relação entre a aptidão à eflorescência [8] e o teor de magnésio no extrato aquoso (o que está possivelmente associado a grande solubilidade do sulfato de magnésio em água). Além disso, foi mostrado que concentrações de sulfatos superiores a $0,05 \%$ - limite de eflorescência de Lipinski - é indicativo de aptidão a eflorescência [5,9].

Vale salientar que a formação de eflorescências está relacionada a fatores muito complexos. Por isto, não é possível estabelecer um percentual de sais solúveis como um limite único para todas as peças cerâmicas e para todas as circunstâncias. Entretanto, o limite de Lipinski demonstrou ser um ótimo valor orientador.

No Brasil, a Embrapa adota a metodologia da condutividade elétrica do extrato de saturação para classificar os solos agrícolas. Uma metodologia rápida e prática a fim de avaliar o teor de sais no solo. O que pode ser adaptado para se estimar o teor de sais solúveis nos corpos cerâmicos. Estudos [10] utilizaram a equação sugerida na literatura [1], equação (A), para converter os valores de condutividade elétrica dos extratos da pasta de saturação de argilas para porcentagem de sais totais em argilas.

$$
\% \text { sais }=\frac{C E 640 P S}{10^{3} 10^{3}}
$$

na qual \%sais é a quantidade de sais presentes na argila, $P S$ é a porcentagem de saturação da argila, que representa o volume necessário para saturar uma determinada quantidade de amostra, $C E$ é a condutividade elétrica, em $\mathrm{dS} / \mathrm{m}$; e 640 é uma constante, utilizada para transformar condutividade elétrica em ppm ou mg/L, que é obtida a partir da correlação entre o teor de sais solúveis e a condutividade elétrica do extrato da pasta de saturação [1]. Foi observada [11], entretanto, uma necessidade de adaptação da equação (A) às características das matérias-primas da região Nordeste, a fim de se ter uma melhor precisão nos resultados. O 
que está associado ao fato da constante que transforma a condutividade elétrica em ppm (ou mg/L) (o valor 640 na equação (A)) ser um fator característico de cada material e variar conforme a relação entre o teor de sais solúveis no material e a condutividade elétrica do seu extrato.

Além de fontes de sais e presença de água na construção, para que ocorra a formação dos depósitos de sais, tal como já mencionado, são necessárias também condições ambientais que proporcionem a percolação da água no material e sua evaporação. Regiões áridas e semi-áridas, como grande parte do Nordeste do Brasil, apresentam condições climáticas que favorecem uma elevada salinização do solo. Esta fonte "inesgotável" de sais solúveis, aliada aos ventos contínuos, faz do Nordeste uma região com elevadas condições para o desenvolvimento de eflorescências e subflorescências. Um outro agravante é a escassez de água na região, que leva produtores a utilizarem no processo de fabricação de produtos cerâmicos águas com elevadas concentrações de sais, muitas vezes provenientes de poços. O que se agrava durante o período de estiagem, quando a concentração de sais solúveis destes poços é muitas vezes superior ao teor de sais da água do mar.

A formação de eflorescências em peças cerâmicas (geralmente tijolos, telhas ou ladrilhos) é um fenômeno que por atuar sempre em detrimento à qualidade dos produtos cerâmicos, preocupa em muito tanto os fabricantes como os construtores. Devido à diversidade de fatores que intervêm na formação destes depósitos salinos, e as variadas conseqüências práticas que têm sobre a qualidade dos produtos cerâmicos, que representam uma fatia considerável dos constituintes da construção, esse trabalho objetiva analisar as características eflorescentes de materiais de construção do Estado da Paraíba.

\section{MATERIAIS E MÉTODOS}

Na elaboração deste trabalho foram utilizados resultados inéditos de estudos desenvolvidos na UFCG no decorrer dos últimos anos, que abrangem dissertações de mestrado em Engenharia Civil e Engenharia Química, e relatórios de pesquisa [10-12].

Os materiais utilizados no desenvolvimento desta pesquisa foram amostras de argilas e de tijolos provenientes de vinte e cinco olarias do estado da Paraíba, sendo numeradas de 1 a 25 . Em cada olaria foi coletada uma amostra de argila e de tijolos referente ao mesmo lote de matéria-prima. Também foram estudados os seguintes materiais de construção: brita, areia e massame (massame é uma denominação local para misturas em diversas proporções de areia fina e argila, geralmente caulinítica, que passam apenas por um tratamento de peneiramento após sua extração), em um total de 16 amostras de cada. As amostras de brita foram trituradas e utilizadas em forma pulverulenta (granulometria $100 \%$ inferior a peneira com abertura de 2,4 mm - n. 8). Detalhes quanto à procedência dos materiais podem ser encontrados em [10-12].

No ensaio para quantificação dos íons presentes nas argilas e nos demais materiais de construção, foi extraído o extrato de saturação dos materiais, segundo método 2.32 da EMBRAPA [13]. As concentrações dos íons $\mathrm{Ca}, \mathrm{Mg}$, Na, K, $\mathrm{Cl}, \mathrm{CO}_{3}$ e $\mathrm{HCO}_{3}$, foram determinas segundo os métodos 2.34 a 2.40 da EMBRAPA [13], enquanto que para os sulfatos, foi utilizado o método turbidimétrico [14].

As medidas de condutividade elétrica dos extratos de saturação foram efetuadas segundo o método 3.33 da Embrapa [13] utilizando um condutivímetro modelo E527 da Metrohm Herisau.

Para determinação das porcentagens de sais solúveis nas amostras de argilas e materiais de construção (brita, areia e massame) foi utilizada a equação (A) modificada, dada por:

$$
\% \text { sais }=\frac{y P S}{10^{3} 10^{3}}
$$

na qual \%sais é a quantidade de sais presentes na argila e nos materiais de construção; PS é a porcentagem de saturação, que representa o volume necessário para saturar uma determinada quantidade de amostra, y é equação da regressão linear entre a condutividade elétrica (CE) e o teor de sais no extrato de saturação $(y=b+a C E)$. O termo y "equivale" ao fator " 640 CE' da equação (A) e tem por objetivo adaptar a equação (A), no que se refere ao teor de sais solúveis e condutividade elétrica do extrato de saturação, às características das amostras da Região Nordeste.

Para determinação das porcentagens de sais solúveis nos tijolos e amostras confeccionadas em laboratório foi utilizada a equação (A) modificada, dada por:

$$
\% \text { sais }=\frac{y \mathrm{Vp}}{10^{3} \mathrm{Pt}}
$$

na qual \%sais é a quantidade de sais presentes nos tijolos e amostras confeccionadas em laboratório, $y$ é equação da regressão linear entre a condutividade elétrica $(C E)$ e o teor de sais no extrato de saturação $(y=\mathrm{b}+\mathrm{a} C E), V_{p}$ é o volume de água destilada utilizado para retirar o extrato dos corpos de prova (l), e Pt é o peso médio dos corpos de prova (g).

Foram confeccionados corpos de prova nas dimensões de $7,5 \mathrm{~cm} \times 5,0 \mathrm{~cm} \times 0,5 \mathrm{~cm}$ por prensagem uniaxial de 20 MPa e formato conforme a Fig. 1. Apenas algumas argilas foram utilizadas na confecção dos corpos de prova em virtude de limitação de material. Os corpos de prova foram obtidos utilizando-se água de amassamento destilada e água altamente salina. A água altamente salina foi proveniente de um poço artesiano localizado na cidade de Juazeirinho, PB, e é utilizada na produção de tijolos e telhas.

A Tabela I apresenta a composição química dessa água, segundo metodologias da EMBRAPA [13]. A umidade de prensagem variou de 8 a 12\% nas amostras processadas 


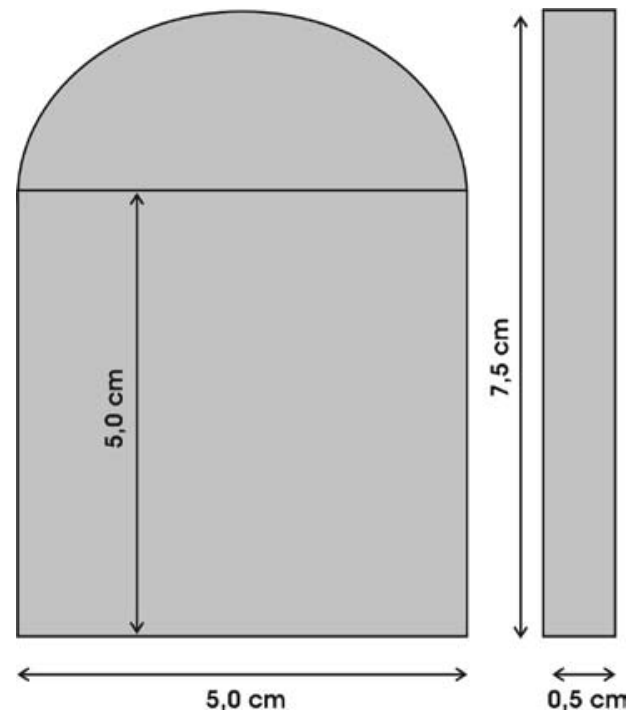

Figura 1: Modelo de corpo de prova

[Figure 1: Model of the sample bodies] com água destilada e de 8 a 16\% nas amostras processadas com água altamente salina. Os corpos de prova foram secos a $110{ }^{\circ} \mathrm{C}$ por 24 h e queimados em forno elétrico, nas temperaturas de 700, 800 e $900{ }^{\circ} \mathrm{C}$. A absorção de água dos tijolos e dos corpos de prova queimados em laboratório foi determinada segundo a norma NBR 8947 [15].

Os tijolos e os corpos de prova confeccionados em laboratório foram submetidos ao ensaio de eflorescência segundo a norma ASTM C67 [16] (duração de sete dias com condições ambiente de evaporação - temperatura de 24 a $27{ }^{\circ} \mathrm{C}$ e umidade de 37 a 90\%). A fim de estudar a aceleração no ensaio de eflorescência, os tijolos e corpos de prova foram também submetidos a condições padronizadas de temperatura e umidade, onde permaneceram durante três dias. Sob estas condições os pares de temperatura e umidade foram: $75{ }^{\circ} \mathrm{C} \pm 5{ }^{\circ} \mathrm{C} \operatorname{com} 51 \% \pm 2 \%$ de umidade - condição definida como $2 ; 90{ }^{\circ} \mathrm{C} \pm 2{ }^{\circ} \mathrm{C}$ com $70 \% \pm 3 \%$ de umidade - condição definida como 3.

Em alguns trabalhos [17-19] utilizou-se o ensaio de

Tabela I - Análise da água altamente salina e do extrato de saturação das argilas.

[Table I-Analysis of the highly saline water and of the saturation extract of the clays.]

\begin{tabular}{|c|c|c|c|c|c|c|c|c|c|c|}
\hline \multirow{2}{*}{ Amostras } & \multicolumn{3}{|c|}{ Cátions (mg/L) } & \multirow[b]{2}{*}{$\mathrm{K}^{+}$} & \multirow[b]{2}{*}{ Total } & \multicolumn{5}{|c|}{ Ânions (mg/L) } \\
\hline & $\mathrm{Ca}^{2+}$ & $\mathrm{Mg}^{2+}$ & $\mathrm{Na}^{+}$ & & & $\mathrm{CO}_{3}^{2-}$ & $\mathrm{CO}_{3} \mathrm{H}^{-}$ & $\mathrm{Cl}^{-}$ & $\mathrm{SO}_{4}^{2-}$ & Total \\
\hline Agua $^{a}$ & 5562,3 & 2620,6 & 13944,0 & 118,4 & 22245,3 & 0,0 & 313,7 & 33225,5 & 14,2 & 33553,2 \\
\hline 1 & 370,5 & 550,0 & 1360,0 & 0,4 & 2280,9 & 0,0 & 136,4 & 1994,1 & 77,9 & 2208,4 \\
\hline 2 & 625,0 & 805,4 & 1880,0 & 0,2 & 3310,7 & 0,0 & 68,2 & 3022,1 & 147,5 & 3237,9 \\
\hline 3 & 319,4 & 364,3 & 1080,0 & 0,6 & 1764,3 & 0,0 & 105,4 & 1577,5 & 32,8 & 1715,8 \\
\hline 4 & 69,3 & 94,7 & 396,0 & 0,5 & 560,5 & 0,0 & 55,8 & 416,5 & 132,3 & 604,7 \\
\hline 5 & 87,8 & 123,9 & 360,0 & 0,5 & 572,2 & 0,0 & 86,8 & 434,3 & 154,4 & 675,5 \\
\hline 6 & 722,5 & 648,6 & 920,0 & 2,1 & 2293,3 & 0,0 & 18,6 & 522,9 & 3072,1 & 3613,6 \\
\hline 7 & 32,2 & 43,7 & 252,0 & 0,2 & 328,2 & 0,0 & 93,0 & 88,6 & 267,1 & 448,8 \\
\hline 8 & 60,0 & 102,0 & 180,0 & 0,3 & 342,4 & 0,0 & 117,8 & 106,3 & 163,2 & 387,4 \\
\hline 9 & 143,4 & 229,2 & 600,0 & 0,6 & 973,6 & 0,0 & 55,8 & 345,6 & 847,1 & 1248,5 \\
\hline 10 & 143,4 & 182,2 & 356,0 & 0,3 & 681,9 & 0,0 & 43,4 & 602,6 & 30,9 & 676,9 \\
\hline 11 & 328,6 & 499,3 & 1640,0 & 0,2 & 2468,2 & 0,0 & 167,4 & 1462,3 & 1148,0 & 2777,8 \\
\hline 12 & 472,4 & 874,5 & 2200,0 & 0,6 & 3547,4 & 0,0 & 62,0 & 3305,7 & 24,5 & 3392,2 \\
\hline 13 & 495,4 & 641,3 & 2280,0 & 0,6 & 3417,2 & 0,0 & 62,0 & 3252,5 & 33,8 & 3348,4 \\
\hline 14 & 282,3 & 382,7 & 3320,0 & 1,1 & 3986,2 & 0,0 & 117,8 & 3217,1 & 602,0 & 3936,8 \\
\hline 15 & 639,1 & 561,1 & 1280,0 & 2,2 & 2482,5 & 0,0 & 365,8 & 1896,6 & 252,0 & 2514,3 \\
\hline 16 & 143,4 & 182,2 & 208,0 & 1,4 & 535,0 & 0,0 & 365,8 & 257,0 & 92,6 & 715,4 \\
\hline 17 & 338,0 & 229,7 & 560,0 & 11,2 & 1138,9 & 0,0 & 136,4 & 638,1 & 396,1 & 1170,6 \\
\hline 18 & 1426,4 & 1093,1 & 3200,0 & 1,9 & 5721,5 & 0,0 & 248,0 & 4768,0 & 1776,0 & 6792,0 \\
\hline 19 & 1370,8 & 2146,0 & 3760,0 & 4,9 & 7281,8 & 0,0 & 241,8 & 5751,8 & 2204,4 & 8198,0 \\
\hline 20 & 930,7 & 1158,7 & 3080,0 & 4,9 & 5174,3 & 0,0 & 186,0 & 4138,8 & 954,4 & 5279,2 \\
\hline 21 & 750,3 & 1315,2 & 3160,0 & 1,7 & 5227,3 & 0,0 & 210,8 & 4316,0 & 608,3 & 5135,2 \\
\hline 22 & 129,7 & 306,1 & 1200,0 & 1,1 & 1636,9 & 0,0 & 167,4 & 1036,9 & 316,2 & 1520,5 \\
\hline 23 & 250,1 & 252,1 & 720,0 & 1,4 & 1223,6 & 0,0 & 62,0 & 670,0 & 41,7 & 773,7 \\
\hline 24 & 13,7 & 58,3 & 100,0 & 0,3 & 172,3 & 0,0 & 99,2 & 44,313 & 66,2 & 209,7 \\
\hline 25 & 111,1 & 327,9 & 2840,0 & 1,5 & 3280,6 & 0,0 & 37,2 & 2499,2 & 28,4 & 2564,9 \\
\hline
\end{tabular}

a água altamente salina 
eflorescência baseado na norma ASTM, adaptando-se escalas para classificar as eflorescências. Assim, numa tentativa de melhor classificar as eflorescências, adotou-se uma escala variando de zero a quatro, com a seguinte nomenclatura: 0 - ausência; 1 - leves; 2 - médias; 3 - consideráveis; 4 abundantes.

$\mathrm{Na}$ análise das britas, areias e massames foram seguidas as recomendações da literatura [17] e feita uma adaptação da metodologia da ASTM [16]. Assim, o ensaio foi executado para cada amostra conforme as seguintes indicações abaixo:

1 - Foram preparados corpos de prova (Fig. 1) com uma argila que não apresentava tendência a eflorescência, quando submetida ao ensaio da ASTM, para agirem como "wicks" (pavios);

2 - Os corpos de prova foram queimados a $800{ }^{\circ} \mathrm{C}$ em forno elétrico, possuindo após queima uma absorção de água em torno de $15 \%$;

3 - Os "wicks" são colocados em recipiente plástico juntamente com $50 \mathrm{~mL}$ de água destilada (imersão de aproximadamente $1 \mathrm{~cm}$ de sua altura), em temperatura e umidade ambientes;

4 - Após dois dias são adicionados $50 \mathrm{~mL}$ de água destilada com $5 \mathrm{~g}$ do material a ser ensaiado (brita, areia ou massame), em seguida a cada dia são adicionados mais 50 $\mathrm{mL}$ da dispersão, até se atingir um total de $25 \mathrm{~g}$ do material ensaiado.

O ensaio teve duração de $7 \mathrm{~d}$ e a temperatura e umidade relativa, neste período, variaram entre 24 e $28^{\circ} \mathrm{C}$ e entre 38 e $95 \%$, respectivamente. Em seguida os "wicks" foram secos a $110{ }^{\circ} \mathrm{C}$ e foi realizada a classificação das eflorescências conforme a escala mencionada anteriormente.

\section{RESULTADOS E DISCUSSÃO}

A Tabela I apresenta os resultados das análises dos extratos de saturação das amostras de argilas. Pode-se observar que os valores de sais solúveis variaram de, aproximadamente, 170 a $7300 \mathrm{mg} / \mathrm{L}$ e de 209 a $8200 \mathrm{mg} / \mathrm{L}$ para os cátions e ânions respectivamente. Em todas as amostras os carbonatos estão ausentes, o que está de acordo com o pH das pastas de saturação (inferiores a 7,1). Pode-se observar elevado teor de sódio e cloro, o que está associado à elevada salinidade do solo da região, que apresenta lençol freático altamente salino, atingindo muitas vezes, salinidade superior a do mar.

A Tabela II apresenta a condutividade elétrica dos extratos de saturação das argilas, dos tijolos e dos corpos de prova queimados em laboratório. Com base nos valores de sais solúveis totais presentes na Tabela I e nos valores de condutividade, foi obtida a correlação entre os saís solúveis no extrato de saturação das argilas e a condutividade do extrato, conforme mostrado na Fig. 2.

A relação entre a condutividade elétrica e a quantidade de sais solúveis no extrato foi obtida predefinindo-se que quando a condutividade for igual a zero a concentração de íons também deve ser igual a zero. Com base na correlação obtida, a constante 640 da equação (A), sugerida na literatura [1], foi substituída pelo coeficiente angular da equação da reta da regressão linear $(y=883,37 C E)$, tornando-a de uso mais específico na determinação da porcentagem de sais presentes em matérias-primas do estado da Paraíba.

A Tabela III apresenta os teores de sais totais para as argilas, tijolos e corpos de prova queimados em laboratório, obtidos utilizando-se as equações (B) e (C). Verifica-se que os teores de sais variam de 0,01 a $1,05 \%$ e de 0,01 a $0,24 \%$ para as argilas e os tijolos respectivamente. Não é observada, tal como esperado, nenhuma correlação entre a quantidade de sais solúveis nas matérias-primas e nos tijolos, já que os sais presentes nos produtos cerâmicos podem ser originados durante a manufatura (influência da atmosfera de queima e até mesmo do armazenamento) ou, pelo contrário, podem ser insolubilizados durante a queima ou gerar produtos voláteis quando submetidos a altas temperaturas de queima ou quando se combinam com outras substâncias.

A Fig. 3 ilustra a variação no teor de sais solúveis das amostras queimadas em laboratório. Pode-se observar que conforme a temperatura de queima aumenta ocorre a diminuição no teor de sais solúveis nas amostras. Isto está provavelmente associado a decomposição e/ou reação dos sais solúveis com constituintes do corpo cerâmico e insolubilização de parte dos sais com a formação de fases vítreas. Essas fases vítreas estariam associadas a pontos de eutéticos que se formam no corpo cerâmico $\left(800-900{ }^{\circ} \mathrm{C}\right)$ em virtude da elevada quantidade de ferro, sódio e potássio nas amostras.

Interessante salientar que nas temperaturas de queima de 700 e $800{ }^{\circ} \mathrm{C}$, o uso de água de amassamento altamente salina conduz a valores de sais superiores aos obtidos com o uso da água destilada (Fig. 3). No entanto, na temperatura de $900{ }^{\circ} \mathrm{C}$ observa-se que o teor de sais é menor com a utilização de água de amassamento altamente salina. O que pode está associado, ao fato da água utilizada apresentar elevado teor de sais que atuam como fundentes durante a queima, estimulando a formação de fases vítreas em menores temperaturas, bem como a emissão de substâncias por volatilização ou formação de sais que não possuem tendências eflorescentes.

Com base na Tabela III não se observa nenhuma relação entre a quantidade de sais solúveis obtidas para os tijolos e as obtidas para os corpos queimados em laboratório, o que ressalta a importância da temperatura, ciclo e atmosfera de queima, bem como da granulometria da amostra e condições de secagem (como por exemplo, a atmosfera) na quantidade de sais solúveis no produto final.

As Tabelas IV e V apresentam os resultados dos ensaios de eflorescência das amostras de tijolos e corpos de prova queimados em laboratório, conforme "escala" apresentada anteriormente nos Materiais e Métodos (escala de 0 a 4). Com base na Tabela IV verifica-se que $80 \%$ das amostras de tijolos apresentaram eflorescências, sendo todas elas de cor branca. Ao se analisar a possível influência da 
Tabela II - Condutividade elétrica do extrato das amostras estudadas.

[Table II - Electrical conductivity of the extracts of the studied samples.]

\begin{tabular}{|c|c|c|c|c|c|c|c|c|}
\hline \multirow{3}{*}{ Amostras } & \multicolumn{8}{|c|}{ Condutividade (dS/m) } \\
\hline & \multirow{2}{*}{ Argilas } & \multirow{2}{*}{ Tijolos } & \multicolumn{3}{|c|}{ Laboratório - Destilada ${ }^{\mathrm{a}}$} & \multicolumn{3}{|c|}{ Laboratório - Salina ${ }^{\mathrm{b}}$} \\
\hline & & & $700{ }^{\circ} \mathrm{C}$ & $800^{\circ} \mathrm{C}$ & $900{ }^{\circ} \mathrm{C}$ & $700{ }^{\circ} \mathrm{C}$ & $800{ }^{\circ} \mathrm{C}$ & $900^{\circ} \mathrm{C}$ \\
\hline 1 & 5,30 & 0,07 & ND & ND & ND & ND & ND & ND \\
\hline 2 & 7,80 & 0,29 & ND & ND & ND & ND & ND & ND \\
\hline 3 & 4,20 & 0,08 & ND & ND & ND & ND & ND & ND \\
\hline 4 & 1,50 & 0,19 & 0,34 & 0,44 & 0,14 & 0,42 & 0,49 & 0,08 \\
\hline 5 & 1,71 & 0,15 & ND & ND & ND & ND & ND & ND \\
\hline 6 & 4,99 & 0,24 & 0,85 & 0,83 & 0,34 & 1,13 & 0,94 & 0,43 \\
\hline 7 & 0,75 & 0,05 & 0,13 & 0,07 & 0,09 & 0,29 & 0,12 & 0,08 \\
\hline 8 & 0,85 & 0,30 & 0,56 & 0,51 & 0,13 & 0,53 & 0,41 & 0,12 \\
\hline 9 & 2,18 & 0,19 & 0,66 & 0,29 & 0,23 & 0,87 & 0,44 & 0,16 \\
\hline 10 & 1,97 & 0,27 & ND & ND & ND & ND & ND & ND \\
\hline 11 & 5,49 & 0,25 & 0,86 & 0,76 & 0,48 & 0,97 & 0,77 & 0,52 \\
\hline 12 & 9,45 & 0,12 & 0,27 & 0,18 & 0,15 & 0,32 & 0,31 & 0,14 \\
\hline 13 & 9,25 & 0,09 & ND & ND & ND & ND & ND & ND \\
\hline 14 & 10,22 & 0,24 & ND & ND & ND & ND & ND & ND \\
\hline 15 & 5,98 & 0,16 & 0,30 & 0,47 & 0,12 & 0,71 & 0,58 & 0,13 \\
\hline 16 & 1,40 & 0,74 & 0,29 & 0,21 & 0,33 & 0,44 & 0,33 & 0,08 \\
\hline 17 & 3,04 & 0,10 & 0,85 & 0,72 & 0,34 & 0,97 & 0,88 & 0,28 \\
\hline 18 & 13,49 & 0,52 & 1,25 & 1,21 & 0,74 & 1,19 & 1,02 & 0,56 \\
\hline 19 & 15,52 & 0,54 & ND & ND & ND & ND & ND & ND \\
\hline 20 & 10,98 & 0,27 & ND & ND & ND & ND & ND & ND \\
\hline 21 & 11,95 & 0,21 & ND & ND & ND & ND & ND & ND \\
\hline 22 & 3,56 & 0,03 & 0,49 & 0,54 & 0,24 & 0,62 & 0,59 & 0,26 \\
\hline 23 & 2,99 & 0,02 & 0,82 & 0,56 & 0,33 & 0,50 & 0,44 & 0,16 \\
\hline 24 & 0,38 & 0,04 & 0,36 & 0,21 & 0,17 & 0,30 & 0,23 & 0,10 \\
\hline 25 & 7,52 & 0,18 & 0,10 & 0,06 & 0,11 & 0,13 & 0,08 & 0,07 \\
\hline
\end{tabular}

${ }^{a}$ amostras queimadas em laboratório e obtidas com água de amassamento destilada; ${ }^{b}$ amostras queimadas em laboratório e obtidas com água de amassamento altamente salina; ND: não determinado

bacia hidrográfica de origem das argilas nos resultados de eflorescência, observa-se que $72 \%$ das amostras da Bacia do Mamanguape (de um total de 11 amostras), $100 \%$ das amostras da Bacia do Paraíba (de um total de 10) e 50\% das amostras da Bacia do Seridó (de um total de 4) apresentaram eflorescências. O que indica que, independentemente da região do estado, os tijolos paraibanos são extremamente susceptíveis a eflorescências.

Vale salientar que na época da coleta das amostras havia olarias que trabalhavam com lenha, com óleo combustível ou com ambos. No caso do uso do óleo, a atmosfera de queima deve ser mais sulfurosa e com maior influência na potencialidade a eflorescência das peças finais. No entanto, não foi possível fazer uma análise quanto ao tipo de combustível utilizado nas olarias e a potencialidade a eflorescência das peças, em virtude das grandes variações dos tipos de combustíveis e das condições de queima (fluxo de ar, intensidade das chamas - quantidade de óleo queimada, etc.) praticadas pelas olarias.

Apesar do pouco número de amostras, os resultados presentes na Tabela IV estão ilustrados na Fig. 4 na forma de gráfico de porcentagem acumulada, a fim de facilitar a visualização da quantidade de amostras que apresentaram eflorescências abaixo de um certo nível (escala de classificação utilizada). Com base na Fig. 4 pode-se observar a significativa diferença no comportamento de eflorescência entre os tijolos e os corpos cerâmicos confeccionados em laboratório, ressaltando, ainda mais, a importância dos parâmetros de processamento. Verificase que apenas $20 \%$ das amostras confeccionadas usando água de amassamento altamente salina apresentaram níveis de eflorescência superiores a 2 , enquanto que $50 \%$ das amostras de tijolos e entre 70 e $80 \%$ das amostras processadas usando água destilada apresentaram níveis 


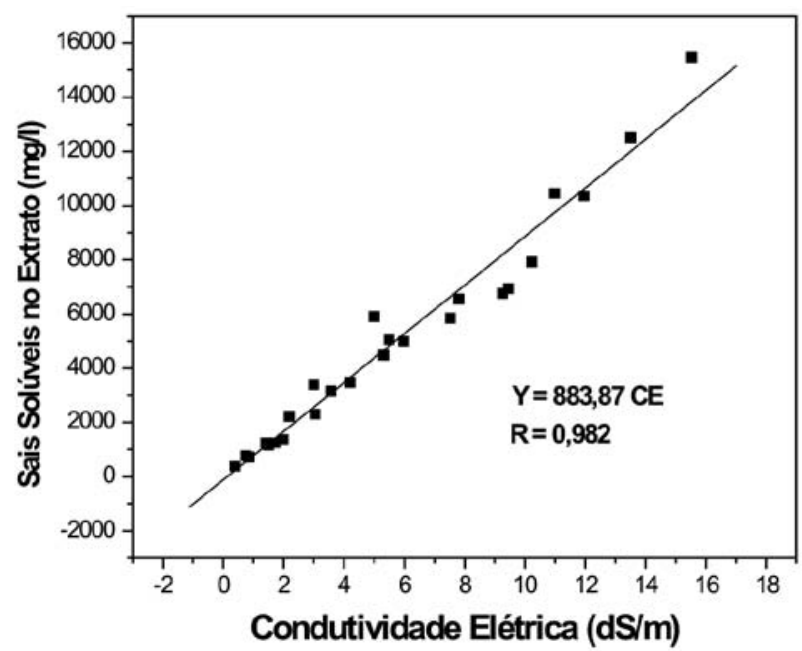

Figura 2: Sais solúveis nos extratos das argilas versus a condutividade elétrica.

[Figure 2: Soluble salts in the extracts of the clays versus the electrical conductivity.]

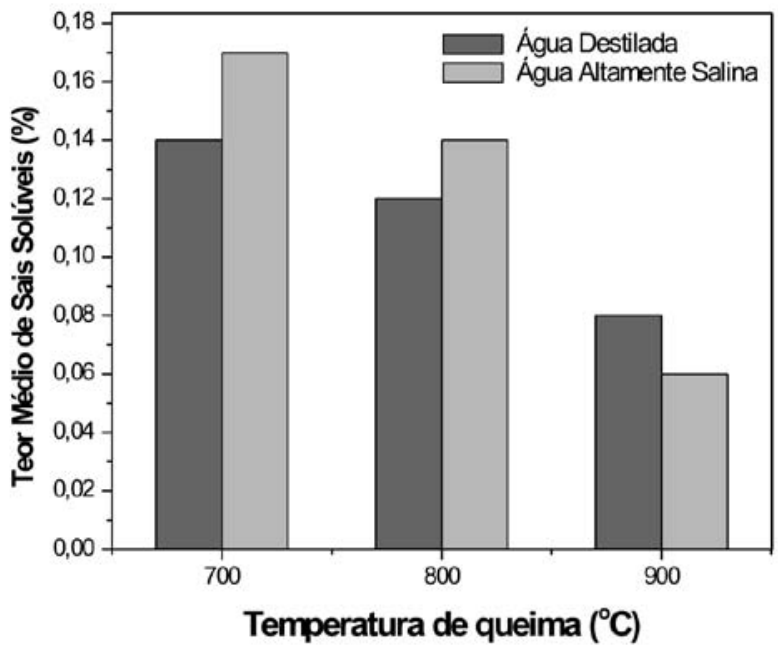

Figura 3: Teor médio de sais solúveis nas amostras processadas em laboratório.

[Figure 3: Percentage of soluble salts in the samples processed in laboratory.]

Tabela III - Porcentagem de sais solúveis nas amostras estudadas.

[Table III - Percentage of soluble salts in the studied samples.]

\begin{tabular}{|c|c|c|c|c|c|c|c|c|}
\hline \multirow{3}{*}{ Amostras } & & \multirow[b]{3}{*}{ Tijolos } & \multicolumn{6}{|c|}{ Porcentagem de Sais (\%) } \\
\hline & \multirow[b]{2}{*}{ Argilas } & & \multicolumn{3}{|c|}{ Laboratório - Destilada $^{a}$} & \multicolumn{3}{|c|}{ Laboratório - Salina $^{\mathrm{b}}$} \\
\hline & & & $700{ }^{\circ} \mathrm{C}$ & $800^{\circ} \mathrm{C}$ & $900^{\circ} \mathrm{C}$ & $700{ }^{\circ} \mathrm{C}$ & $800^{\circ} \mathrm{C}$ & $900^{\circ} \mathrm{C}$ \\
\hline 1 & 0,30 & 0,02 & ND & ND & ND & ND & ND & ND \\
\hline 2 & 0,44 & 0,11 & ND & ND & ND & ND & ND & ND \\
\hline 3 & 0,22 & 0,02 & ND & ND & ND & ND & ND & ND \\
\hline 4 & 0,07 & 0,05 & 0,09 & 0,10 & 0,04 & 0,10 & 0,12 & 0,02 \\
\hline 5 & 0,12 & 0,04 & ND & ND & ND & ND & ND & ND \\
\hline 6 & 0,26 & 0,07 & 0,24 & 0,21 & 0,09 & 0,29 & 0,25 & 0,12 \\
\hline 7 & 0,04 & 0,01 & 0,04 & 0,03 & 0,03 & 0,08 & 0,04 & 0,03 \\
\hline 8 & 0,03 & 0,10 & 0,14 & 0,10 & 0,04 & 0,12 & 0,09 & 0,03 \\
\hline 9 & 0,10 & 0,06 & 0,16 & 0,07 & 0,06 & 0,19 & 0,10 & 0,04 \\
\hline 10 & 0,11 & 0,06 & ND & ND & ND & ND & ND & ND \\
\hline 11 & 0,33 & 0,06 & 0,24 & 0,22 & 0,13 & 0,26 & 0,21 & 0,14 \\
\hline 12 & 0,43 & 0,03 & 0,06 & 0,04 & 0,04 & 0,07 & 0,07 & 0,04 \\
\hline 13 & 0,52 & 0,03 & ND & ND & ND & ND & ND & ND \\
\hline 14 & 0,80 & 0,07 & ND & ND & ND & ND & ND & ND \\
\hline 15 & 0,28 & 0,05 & 0,09 & 0,13 & 0,04 & 0,21 & 0,18 & 0,04 \\
\hline 16 & 0,07 & 0,24 & 0,09 & 0,07 & 0,12 & 0,12 & 0,11 & 0,03 \\
\hline 17 & 0,12 & 0,03 & 0,23 & 0,20 & 0,09 & 0,27 & 0,24 & 0,08 \\
\hline 18 & 0,55 & 0,13 & 0,32 & 0,30 & 0,19 & 0,32 & 0,28 & 0,16 \\
\hline 19 & 1,05 & 0,20 & ND & ND & ND & ND & ND & ND \\
\hline 20 & 0,50 & 0,11 & ND & ND & ND & ND & ND & ND \\
\hline 21 & 0,50 & 0,08 & ND & ND & ND & ND & ND & ND \\
\hline 22 & 0,11 & 0,01 & 0,13 & 0,14 & 0,07 & 0,18 & 0,17 & 0,07 \\
\hline 23 & 0,11 & 0,01 & 0,19 & 0,13 & 0,08 & 0,14 & 0,12 & 0,05 \\
\hline 24 & 0,01 & 0,01 & 0,01 & 0,06 & 0,06 & 0,09 & 0,08 & 0,04 \\
\hline 25 & 0,40 & 0,05 & 0,03 & 0,03 & 0,04 & 0,04 & 0,03 & 0,03 \\
\hline
\end{tabular}

${ }^{a}$ amostras queimadas em laboratório e obtidas com água de amassamento destilada; ${ }^{b}$ amostras queimadas em laboratório e obtidas com água de amassamento altamente salina; ND: não determinado 
Tabela IV - Resultado do ensaio de eflorescência realizado segundo a metodologia ASTM.

[Table IV-Results of the efflorescence test according to the ASTM methodology.]

\begin{tabular}{|c|c|c|c|c|c|c|c|}
\hline \multirow{2}{*}{ Amostras } & \multirow{2}{*}{ Tijolos } & \multicolumn{3}{|c|}{ Laboratório - Destilada } & \multicolumn{3}{|c|}{ Laboratório - Salina ${ }^{\mathrm{b}}$} \\
\hline & & $700^{\circ} \mathrm{C}$ & $800{ }^{\circ} \mathrm{C}$ & $900{ }^{\circ} \mathrm{C}$ & $700{ }^{\circ} \mathrm{C}$ & $800^{\circ} \mathrm{C}$ & $900{ }^{\circ} \mathrm{C}$ \\
\hline 1 & 0 & ND & ND & ND & ND & ND & ND \\
\hline 2 & 3 & ND & ND & ND & ND & ND & ND \\
\hline 3 & 0 & ND & ND & ND & ND & ND & ND \\
\hline 4 & 4 & 3 & 3 & 2 & 3 & 3 & 1 \\
\hline 5 & 3 & ND & ND & ND & ND & ND & ND \\
\hline 6 & 3 & 4 & 4 & 1 & 4 & 4 & 3 \\
\hline 7 & 0 & 1 & 0 & 1 & 1 & 1 & 1 \\
\hline 8 & 4 & 3 & 2 & 1 & 3 & 3 & 1 \\
\hline 9 & 3 & 3 & 2 & 1 & 4 & 3 & 1 \\
\hline 10 & 1 & ND & ND & ND & ND & ND & ND \\
\hline 11 & 1 & 4 & 3 & 2 & 4 & 4 & 3 \\
\hline 12 & 2 & 3 & 1 & 1 & 3 & 2 & 1 \\
\hline 13 & 1 & ND & ND & ND & ND & ND & ND \\
\hline 14 & 3 & ND & ND & ND & ND & ND & ND \\
\hline 15 & 3 & 2 & 3 & 1 & 4 & 4 & 2 \\
\hline 16 & 4 & 2 & 1 & 1 & 3 & 2 & 1 \\
\hline 17 & 1 & 4 & 3 & 4 & 4 & 4 & 2 \\
\hline 18 & 4 & 4 & 4 & 4 & 4 & 4 & 4 \\
\hline 19 & 3 & ND & ND & ND & ND & ND & ND \\
\hline 20 & 3 & ND & ND & ND & ND & ND & ND \\
\hline 21 & 2 & ND & ND & ND & ND & ND & ND \\
\hline 22 & 1 & 3 & 3 & 3 & 4 & 3 & 1 \\
\hline 23 & 0 & 4 & 2 & 2 & 3 & 2 & 1 \\
\hline 24 & 0 & 2 & 1 & 1 & 2 & 1 & 1 \\
\hline 25 & 1 & 1 & 1 & 1 & 1 & 1 & 1 \\
\hline
\end{tabular}

a amostras queimadas em laboratório e obtidas com água de amassamento destilada; ${ }^{b}$ amostras queimadas em laboratório e obtidas com água de amassamento altamente salina; ND: não determinado

Tabela $\mathrm{V}$ - Resultados do ensaio de eflorescência realizado segundo as condições 2 e 3 .

[Table $V$-Results of the efflorescence test according to the conditions 2 and 3.]

\begin{tabular}{|c|c|c|c|c|c|c|c|c|c|c|c|c|}
\hline \multirow{3}{*}{ Amostras } & \multicolumn{6}{|c|}{ Condição $2^{\mathrm{a}}$} & \multicolumn{6}{|c|}{ Condição $3^{b}$} \\
\hline & \multicolumn{3}{|c|}{ Água Destilada } & \multicolumn{3}{|c|}{ Água Salina } & \multicolumn{3}{|c|}{ Água Destilada } & \multicolumn{3}{|c|}{ Água Salina } \\
\hline & $700^{\circ} \mathrm{C}$ & $800^{\circ} \mathrm{C}$ & $900^{\circ} \mathrm{C}$ & $700{ }^{\circ} \mathrm{C}$ & $800^{\circ} \mathrm{C}$ & $900{ }^{\circ} \mathrm{C}$ & $700^{\circ} \mathrm{C}$ & $800^{\circ} \mathrm{C}$ & $900{ }^{\circ} \mathrm{C}$ & $700^{\circ} \mathrm{C}$ & $800^{\circ} \mathrm{C}$ & $900^{\circ} \mathrm{C}$ \\
\hline 4 & 3 & 2 & 2 & 2 & 3 & 1 & 3 & 2 & 2 & 2 & 2 & 1 \\
\hline 6 & 3 & 3 & 2 & 4 & 4 & 3 & 4 & 3 & 2 & 4 & 3 & 3 \\
\hline 7 & 1 & 0 & 0 & 1 & 1 & 1 & 1 & 0 & 1 & 0 & 0 & 1 \\
\hline 8 & 3 & 2 & 1 & 3 & 2 & 1 & 3 & 3 & 1 & 3 & 2 & 1 \\
\hline 9 & 3 & 1 & 1 & 4 & 3 & 1 & 2 & 1 & 1 & 4 & 3 & 1 \\
\hline 11 & 4 & 2 & 1 & 3 & 3 & 2 & 3 & 2 & 2 & 3 & 3 & 2 \\
\hline 12 & 2 & 1 & 1 & 3 & 2 & 1 & 2 & 1 & 1 & 3 & 2 & 1 \\
\hline 15 & 3 & 3 & 1 & 3 & 3 & 1 & 3 & 3 & 1 & 3 & 3 & 2 \\
\hline 16 & 2 & 2 & 2 & 3 & 2 & 1 & 2 & 1 & 1 & 2 & 1 & 1 \\
\hline 17 & 4 & 3 & 2 & 3 & 4 & 2 & 4 & 3 & 2 & 3 & 3 & 2 \\
\hline 18 & 4 & 3 & 4 & 4 & 4 & 4 & 4 & 4 & 3 & 4 & 3 & 3 \\
\hline 22 & 3 & 3 & 2 & 3 & 2 & 2 & 3 & 3 & 3 & 3 & 3 & 3 \\
\hline 23 & 3 & 3 & 1 & 3 & 1 & 1 & 3 & 2 & 2 & 3 & 2 & 1 \\
\hline 24 & 3 & 1 & 1 & 2 & 1 & 1 & 2 & 1 & 1 & 2 & 1 & 1 \\
\hline 25 & 1 & 1 & 1 & 1 & 1 & 1 & 1 & 1 & 1 & 1 & 1 & 1 \\
\hline
\end{tabular}

${ }^{a}$ Temperatura $75{ }^{\circ} \mathrm{C} \pm 5{ }^{\circ} \mathrm{C}$ e umidade relativa $51 \% \pm 2 \% ;{ }^{b}$ Temperatura $90{ }^{\circ} \mathrm{C} \pm 2{ }^{\circ} \mathrm{C}$ e umidade relativa $70 \% \pm 3 \%$ 


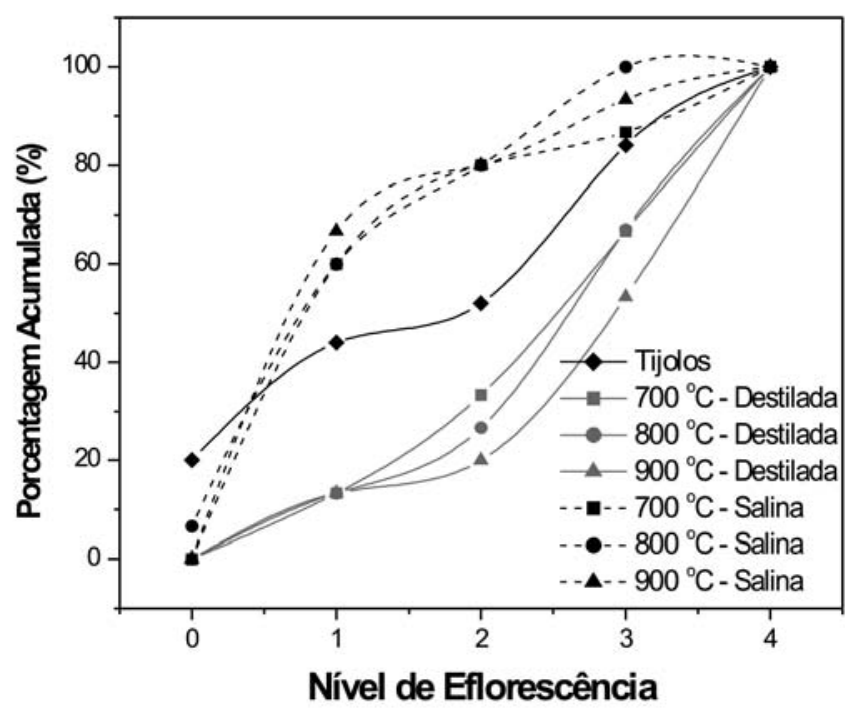

Figura 4: Distribuição dos níveis de eflorescências. [Figure 4: Distribution of the efflorescence levels.]

de eflorescência superiores a 2 .

Os resultados de eflorescências ilustrados na Fig. 4 estão de acordo com os resultados de teor de sais solúveis quando da queima a $900{ }^{\circ} \mathrm{C}$ (Fig. 3), já que se observou que o teor de sais nas amostras confeccionadas com água altamente salina era menor nesta temperatura. No entanto, o teor médio de sais solúveis nas demais temperaturas era maior nas amostras preparadas com água salina, enquanto que a quantidade de peças com maiores níveis de eflorescências é menor (Fig. 4), comparativamente as amostras processadas com água destilada. Essa aparente discrepância pode está associada a

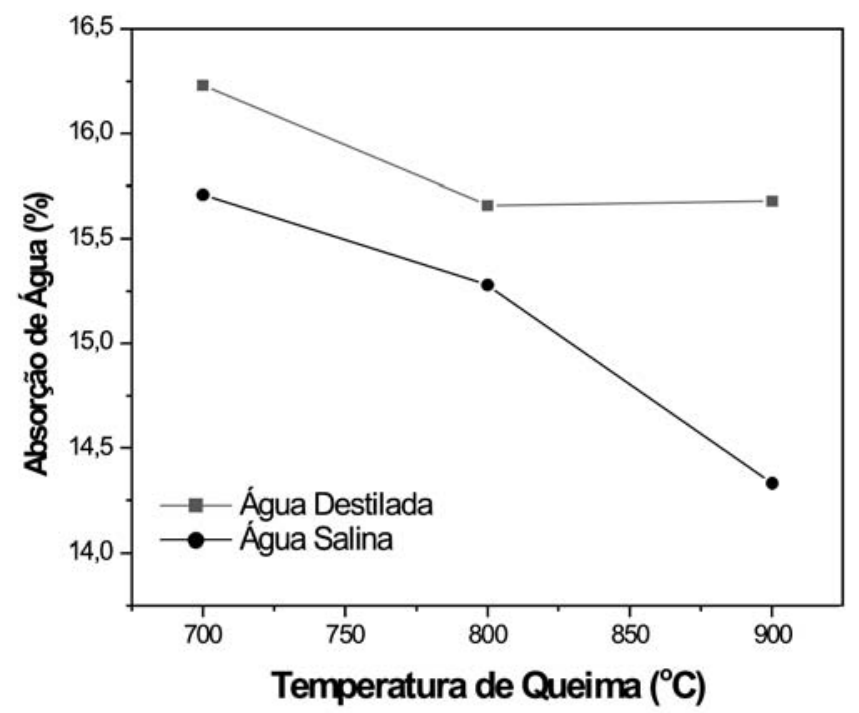

Figura 5: Absorção de água das amostras processadas em laboratório.

[Figure 5: Water absorption of the samples processed in laboratory.] dois pontos; i) a absorção de água das amostras processadas com água salina (Fig. 5) é menor do que a absorção das amostras processadas com água destilada (efeito fundente dos sais presentes na água) em todas as temperaturas de queima. Assim, uma maior dificuldade na percolação da água dificultaria a formação de eflorescências (vale ressaltar, que a diferença nos valores de absorção é muito pequena); e ii) a aptidão a eflorescência, bem como sua intensidade na peça, estão intimamente associados aos tipos de sais presentes e não necessariamente relacionados à quantidade de sais solúveis $[5,8]$. Assim, pode ocorrer que os corpos de prova processados com água salina apresentem sais solúveis que não tenham tendência a eflorescência ou que gerem eflorescências que não apresentam contraste acentuado de cor com o corpo da peça, fazendo com que as eflorescências (ou sua intensidade) passem um tanto despercebidas durante a inspeção após ensaio. Nesse sentido, vale salientar, que dados da literatura $[5,20]$ comprovam que a composição dos sais solúveis no interior das peças cerâmicas não é a mesmas das eflorescências na sua superfície, fortalecendo a hipótese que os sais presentes nas amostras processadas com água salina podem apresentar menor tendência a eflorescência.

A Fig. 6 ilustra os dados presentes na Tabela V. Verifica-se que a utilização de elevadas temperaturas, a fim de acelerar o ensaio de eflorescência, mascara o desenvolvimento das eflorescências nas peças, observando-se que sob as condições 2 e 3 não há diferença significativa no comportamento das peças processadas com água destilada e com água salina (na mesma temperatura de queima). Verifica-se que há um aumento da quantidade de peças com maiores níveis de eflorescências no caso dos corpos de prova processados com água salina e uma diminuição nessa quantidade nos corpos de prova processados com água destilada - comparativamente a metodologia da ASTM. O que está estreitamente associado a maior cinética de difusão e evaporação da água aquecida, de sua maior capacidade de solubilização e as características microestruturais inerentes a cada temperatura de queima.

O aumento da quantidade de peças com maiores níveis de eflorescência dos corpos de prova processados com água salina, quando do ensaio nas condições 2 e 3 (relativamente a condição de temperatura ambiente da água - metodologia ASTM), está relacionado ao fato de que a água mais aquecida tem um maior poder de solubilização dos sais. Assim, nos corpos de prova queimados a 700 e $800{ }^{\circ} \mathrm{C}$ ocorreu uma maior solubilização dos seus sais e por conseguinte maior quantidade de peças com elevados níveis de eflorescências. Já nas peças queimadas a $900^{\circ} \mathrm{C}$, apesar do maior poder de solubilização da água aquecida, o efeito da temperatura de queima se fez predominante, não havendo aumento na quantidade de peças com elevados níveis de eflorescências. Com uma maior temperatura de queima a microestrutura apresenta capilares de menor diâmetro, poros não interconectados, uma absorção de água menor, e uma maior quantidade de sais insolubilizados, seja por estarem imersos em fases vítreas ou por terem reagido com outros 
constituintes do corpo cerâmico, formando compostos não solúveis em água, ou produtos volatilizados. O que impossibilita que a água "arraste" uma grande quantidade de sais para a superfície da peça.

No caso das peças processadas com água destilada a diminuição na quantidade de peças com elevados níveis de eflorescências (comparativamente a condição de temperatura ambiente da água - metodologia ASTM) está associada ao fato de que não há grande quantidade de sais com dificuldade de serem solubilizados (tal como nas amostras processadas com água salina). Assim, a água aquecida, com uma maior capacidade de difusão e evaporação, migra rapidamente pelo corpo do material cerâmico e evapora rapidamente não conseguindo conduzir a mesma quantidade de sais a superfície
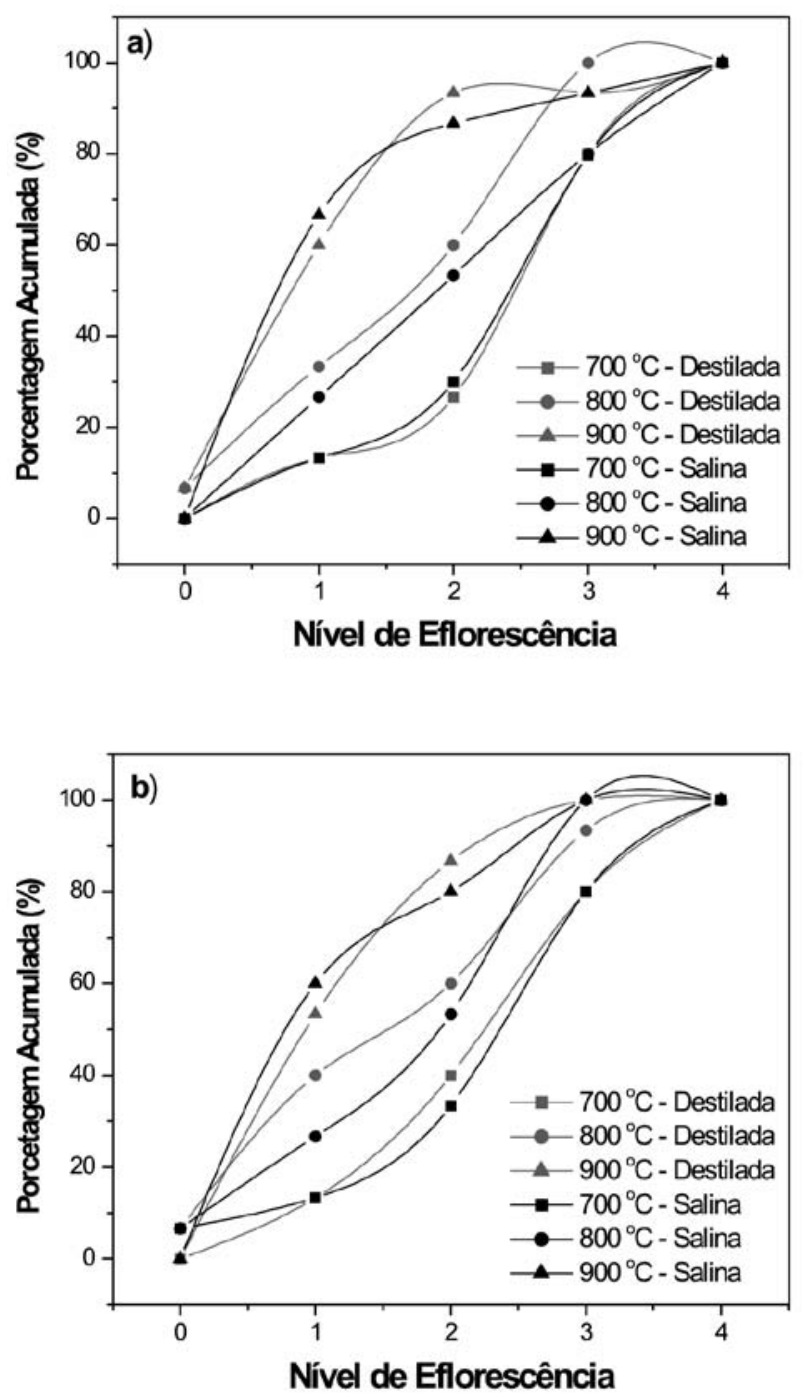

Figura 6: Distribuição dos níveis de eflorescências, (a) condição 2 e (b) condição 3.

[Figure 6: Distribution of the efflorescence levels, (a) condition 2 and (b) condition 3.] da amostra que a observada com a metodologia da ASTM. O que se intensifica conforme se aumenta a temperatura de queima, já que quanto maior a temperatura de queima, menor a quantidade de sais "disponíveis" (ou facilmente "disponíveis") para serem solubilizados pela água. Então, ao se analisar a temperatura de queima de $900{ }^{\circ} \mathrm{C}$, por exemplo, observa-se que a quantidade de peças com elevados níveis de eflorescências diminui drasticamente, relativamente a metodologia da ASTM (Fig. 4 e Fig. 6), o que é um indicativo que pode está ocorrendo a formação de subflorescências (criptoflorescências) em virtude da rápida evaporação da água.

Com base nos resultados verifica-se que a tentativa de acelerar o ensaio com o aquecimento da água (mas também com citações na literatura [21] abordando o uso de ventilação forçada), pode conduzir a resultados de estimulação ou inibição da formação de eflorescências conforme seja a rede capilar, as fases presentes e os tipos de sais presentes, o que é totalmente indesejável em uma metodologia de ensaio. Ressaltando, que várias normas técnicas (ASTM, espanhola, UNE, francesa, NF) utilizam água na temperatura ambiente, no entanto o ensaio decorre no mínimo de 4 a 5 dias, o que é um tanto incômodo do ponto de vista industrial, já que o ideal é se ter informações sobre as características eflorescentes de um lote antes de sua expedição. Vale salientar que estudos visando acelerar o ensaio de eflorescência estão sendo desenvolvidos, a fim de ter uma metodologia rápida mas sem o inconveniente de ser influenciada pelos tipos de sais presentes.

Com base nos resultados das Tabelas III, IV e V podese observar que não há relação direta entre o grau de eflorescência dos tijolos e os sais contidos nas argilas e também, entre os teores de sais solúveis das argilas e dos tijolos. Já que o teor de sais solúveis e o aparecimento de eflorescências estão intimamente associados às características de processamento.

A Fig. 7 evidencia que não há uma relação bem definida entre a quantidade de sais solúveis dos tijolos e das amostras queimadas em laboratório e o seu nível de eflorescência. Resultados da literatura [8] evidenciam que a quantidade de sais solúveis que as peças cerâmicas contêm não se constitui uma medida adequada de sua aptidão para eflorescência. Com base na Fig. 7, no entanto, pode-se observar que há uma relação diretamente proporcional entre o teor de sais solúveis e os níveis de eflorescência e que, de forma geral, teores de até $0,025 \%$ de sais solúveis não conduzem a formação de eflorescências. Esse valor é bem semelhante ao limite de Lipinski $(0,05 \%)$, no entanto, inferior ao valor de $0,5 \%$ indicado na literatura [22].

Observando-se a Fig. 7 verifica-se que o comportamento dos tijolos e dos corpos de prova queimados em laboratório é similar. Entretanto, pequenos valores de sais solúveis nos tijolos, como por exemplo $0,05 \%$, conduzem a elevados níveis de eflorescências, o que não é observado nas peças queimadas em laboratório, que com esse teor de sais, apenas apresentam leves eflorescências. $\mathrm{O}$ que ressalta mais uma vez a influência do tipo de sais presentes na amostra no 

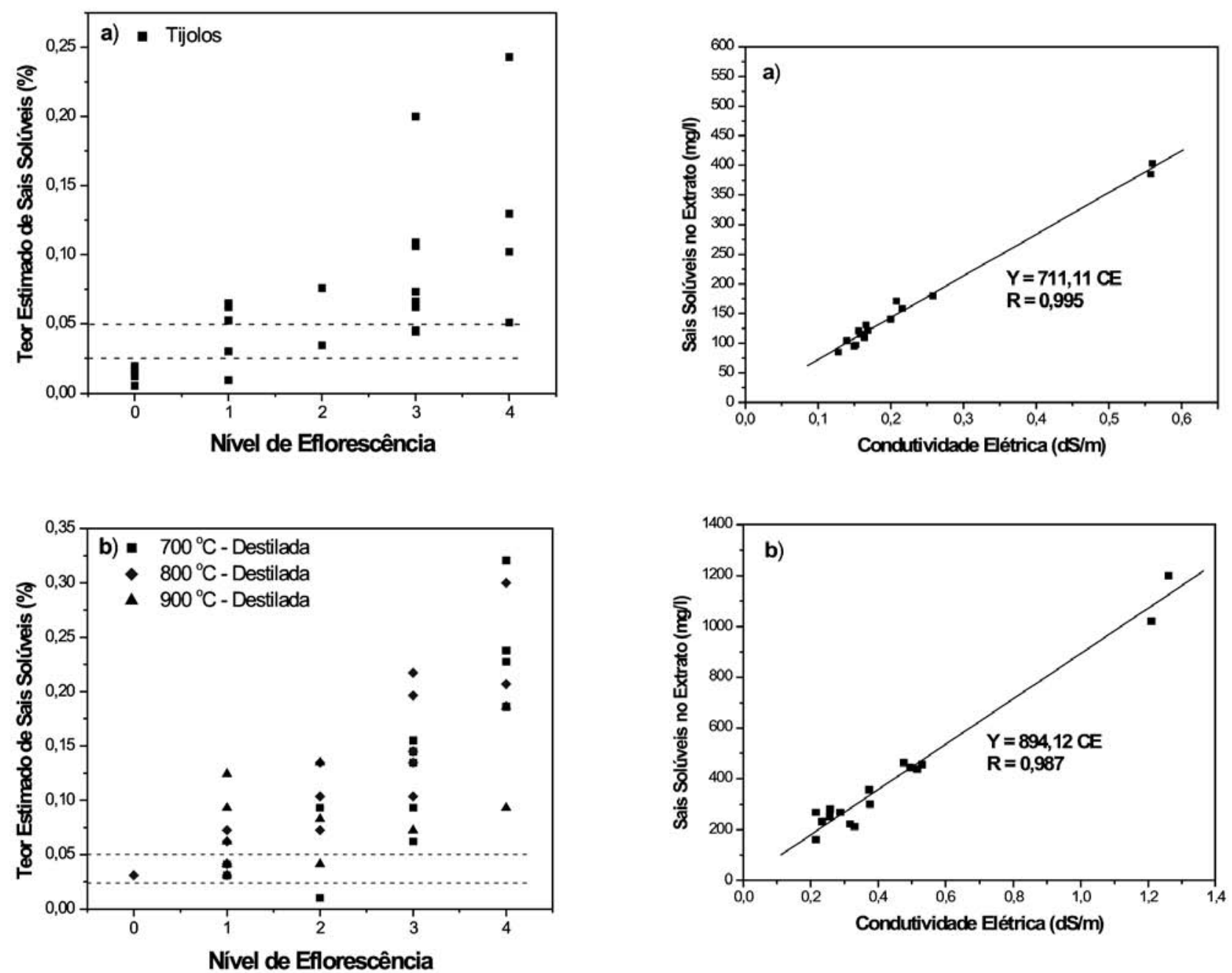
a) - Brita
b) - Areia
c) - Massame

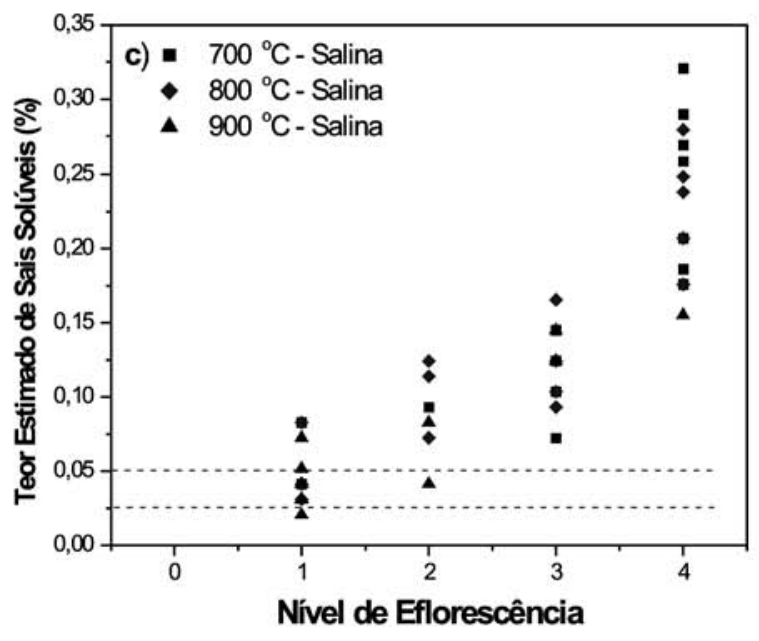

Figura 7: Sais solúveis versus níveis de eflorescências, (a) tijolos, (b) corpos de prova processados com água destilada e (c) corpos de prova processados com água salina.

[Figure 7: Soluble salts versus efflorescence levels, (a) bricks, (b) samples processed with distilled water and (c) samples processed with saline water.]

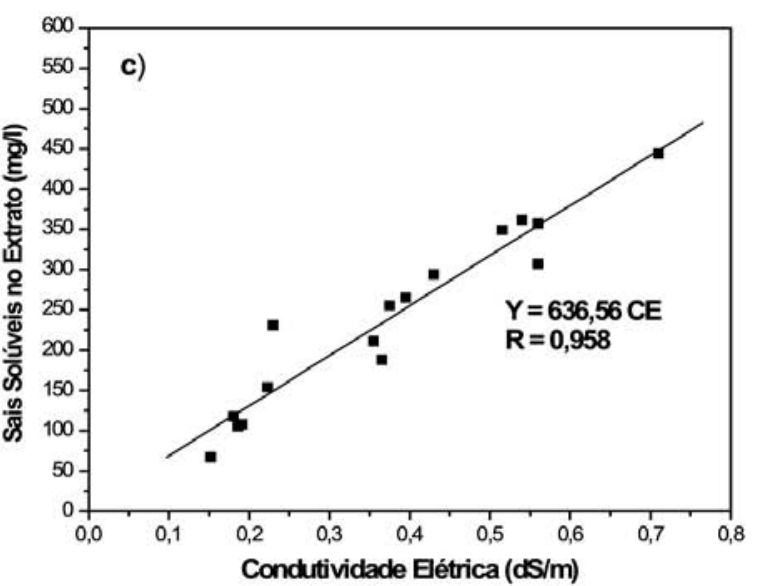

Figura 8: Sais solúveis nos extratos versus a condutividade elétrica.

[Figure 8: Soluble salts in the extracts versus the electrical conductivity.] 
Tabela VI - Sais no extrato, condutividade elétrica e porcentagem de sais solúveis nas amostras de brita, areia e massame. [Table VI-Salts in the extract, electrical conductivity and percentage of soluble salts in the building materials.]

\begin{tabular}{ccccccccccc}
\hline \multirow{3}{*}{ Amostras } & \multicolumn{3}{c}{ Brita } & \multicolumn{3}{c}{ Areia } & \multicolumn{3}{c}{ Massame } \\
\cline { 2 - 9 } & $\begin{array}{c}\text { Sais }^{\mathrm{a}} \\
(\mathrm{mg} / \mathrm{L})\end{array}$ & $\begin{array}{c}\text { Cond. }^{\mathrm{b}} \\
(\mathrm{dS} / \mathrm{m})\end{array}$ & $\begin{array}{c}\text { Por. }^{\mathrm{c}} \\
(\%)\end{array}$ & $\begin{array}{c}\text { Sais }^{\mathrm{a}} \\
(\mathrm{mg} / \mathrm{L})\end{array}$ & $\begin{array}{c}\text { Cond. }^{\mathrm{b}} \\
(\mathrm{dS} / \mathrm{m})\end{array}$ & $\begin{array}{c}\text { Por. }^{\mathrm{c}} \\
(\%)\end{array}$ & $\begin{array}{c}\text { Sais }^{\mathrm{a}} \\
(\mathrm{mg} / \mathrm{L})\end{array}$ & $\begin{array}{c}\text { Cond. }^{\mathrm{b}} \\
(\mathrm{dS} / \mathrm{m})\end{array}$ & $\begin{array}{c}\text { Por. }^{\mathrm{c}} \\
(\%)\end{array}$ \\
\hline 1 & 140,0 & 0,20 & 0,00 & 443,9 & 0,50 & 0,01 & 293,9 & 0,43 & 0,01 \\
2 & 115,0 & 0,16 & 0,00 & 212,6 & 0,33 & 0,01 & 444,1 & 0,71 & 0,01 \\
3 & 171,3 & 0,21 & 0,00 & 463,6 & 0,48 & 0,01 & 349,6 & 0,52 & 0,01 \\
4 & 97,0 & 0,15 & 0,00 & 222,0 & 0,32 & 0,01 & 107,9 & 0,19 & 0,00 \\
5 & 179,6 & 0,26 & 0,00 & 268,2 & 0,22 & 0,00 & 154,0 & 0,22 & 0,00 \\
6 & 120,3 & 0,16 & 0,00 & 301,6 & 0,38 & 0,01 & 105,1 & 0,19 & 0,00 \\
7 & 384,7 & 0,56 & 0,01 & 251,3 & 0,26 & 0,00 & 211,1 & 0,36 & 0,01 \\
8 & 85,0 & 0,13 & 0,00 & 355,9 & 0,37 & 0,01 & 231,1 & 0,23 & 0,00 \\
9 & 104,2 & 0,14 & 0,00 & 1020,1 & 1,21 & 0,03 & 307,1 & 0,56 & 0,01 \\
10 & 109,8 & 0,16 & 0,00 & 161,7 & 0,22 & 0,00 & 357,1 & 0,56 & 0,01 \\
11 & 114,7 & 0,16 & 0,00 & 1199,1 & 1,26 & 0,03 & 188,0 & 0,37 & 0,01 \\
12 & 121,0 & 0,17 & 0,00 & 281,4 & 0,26 & 0,01 & 67,1 & 0,15 & 0,00 \\
13 & 131,0 & 0,17 & 0,00 & 437,0 & 0,52 & 0,00 & 361,8 & 0,54 & 0,01 \\
14 & 403,1 & 0,56 & 0,01 & 268,1 & 0,29 & 0,01 & 265,2 & 0,40 & 0,00 \\
15 & 95,2 & 0,15 & 0,00 & 456,0 & 0,53 & 0,01 & 255,0 & 0,38 & 0,00 \\
16 & 158,4 & 0,22 & 0,00 & 232,0 & 0,23 & 0,00 & 118,0 & 0,18 & 0,00 \\
\hline
\end{tabular}

${ }^{a}$ quantidade de sais totais no extrato $(\mathrm{mg} / \mathrm{L}) ;{ }^{b}$ condutividade elétrica do extrato $(\mathrm{dS} / \mathrm{m}) ;{ }^{c}$ porcentagem de sais solúveis nas amostras (\%)

aparecimento e intensidade das eflorescências.

Com base na análise química dos extratos de saturação das amostras de brita, areia e massame, verificou-se que: as amostras dos extratos de brita apresentaram teores máximos de sulfatos e cloretos de 23 e $160 \mathrm{mg} / \mathrm{L}$ respectivamente e resíduo sólido máximo de $400 \mathrm{mg} / \mathrm{L}$, não ultrapassando o limite ditado pela normalização brasileira [23] para concreto armado (sulfatos $<500 \mathrm{mg} / \mathrm{L}$, cloretos $<300 \mathrm{mg} / \mathrm{L}$, resíduo sólido $<500 \mathrm{mg} / \mathrm{L}$ ); as amostras dos extratos de areia apresentaram teores máximos de sulfatos e cloretos de 22 e $355 \mathrm{mg} / \mathrm{L}$ respectivamente e resíduo sólido máximo de $1038 \mathrm{mg} / \mathrm{L}$, com exceção das amostras 9 e 11 as demais apresentam valores de resíduo e concentração iônica dentro dos limites da normalização [23]. As amostras dos extratos de massame apresentaram teores máximos de sulfatos e cloretos de 20 e $150 \mathrm{mg} / \mathrm{L}$ respectivamente e resíduo sólido máximo de $420 \mathrm{mg} / \mathrm{L}$, não ultrapassando assim, os limites da normalização [23].

A Tabela VI apresenta a quantidade total de sais solúveis obtidas nos extratos de saturação das britas, areias e massames, bem como a condutividade elétrica do extrato. Com base na Tabela VI, a Fig. 8 ilustra as correlações obtidas entre a quantidade de sais no extrato e sua condutividade elétrica. Deve-se salientar que, as relações entre a condutividade e a quantidade de sais solúveis no extrato foram obtidas predefinindo-se que quando a condutividade for igual a zero a concentração de íons também deve ser igual a zero. Com base nas correlações obtidas ( $y=711,11 C E$ para as britas, $y$ $=894,12 C E$ para a areia e $y=636,56 C E$ para o massame) e utilizando-se a equação (B) foram determinadas as quantidades de sais solúveis nas amostras. Pode-se observar que os valores não ultrapassaram $0,03 \%$, situado-se em sua maioria entre 0,00 e $0,01 \%$.

Os resultados dos ensaios de eflorescência estão contidos na Tabela VII. Observa-se que a grande maioria das amostras analisadas não apresentaram características eflorescentes, o que é um ótimo indicativo de que os materiais de construção não cerâmicos (brita, areia e massame) utilizados na Paraíba

Tabela VII - Resultado do ensaio de eflorescência na amostras de brita, areia e massame.

[Table VII - Results of the efflorescence test in the samples of building materials.]

\begin{tabular}{lcccccccccccccccc}
\hline Amostras & 01 & 02 & 03 & 04 & 05 & 06 & 07 & 08 & 09 & 10 & 11 & 12 & 13 & 14 & 15 & 16 \\
\hline Brita & 0 & 0 & 1 & 0 & 0 & 0 & 0 & 0 & 0 & 0 & 1 & 1 & 0 & 0 & 0 & 0 \\
Areia & 0 & 0 & 0 & 0 & 0 & 0 & 2 & 0 & 0 & 0 & 0 & 0 & 0 & 1 & 1 & 0 \\
Massame & 0 & 0 & 0 & 0 & 0 & 0 & 0 & 0 & 0 & 0 & 0 & 0 & 1 & 0 & 0 & 0 \\
\hline
\end{tabular}


não apresentam contaminações, como por exemplo de água salina ou compostos nitrogenados. Com base na Tabela VI e VII verifica-se que não há uma correlação direta entre a quantidade de sais solúveis nas amostras e o nível de eflorescência. No entanto, observa-se que, de forma geral, o valor de $0,025 \%$ pode realmente ser utilizado como um limite indicativo para a susceptibilidade a eflorescência ou não de uma amostra.

Estudos sobre eflorescências em argamassas e concretos estão em andamento e brevemente serão publicados.

\section{CONCLUSÕES}

Este trabalho teve como objetivo analisar as características eflorescentes de materiais de construção do Estado da Paraíba. Pode-se concluir que: a) não há uma correlação bem definida entre o teor de sais solúveis das matériasprimas e o nível de eflorescência das peças cerâmicas; b) que as características de processamento têm uma influência marcante no teor de sais solúveis e no nível de eflorescência dos produtos cerâmicos; c) que a absoluta maioria dos tijolos analisados tem elevada tendência a eflorescência; d) que a salinidade da água de amassamento influi no teor de sais solúveis dos corpos cerâmicos e na sua tendência eflorescente; e) que a aceleração do ensaio de eflorescência, com o uso de água aquecida, pode falsear a tendência a eflorescência das peças cerâmicas; f) que o teor de $0,025 \%$ de sais solúveis nos corpos cerâmicos aparenta ser um limite adequado para avaliar a aptidão, ou não, das peças para apresentarem eflorescências; g) os materiais de construção não cerâmicos na forma de areias, massames e britas não apresentam contaminações na forma de sais solúveis que conduzam a características eflorescentes.

\section{REFERÊNCIAS}

[1] L. A. Richards, Agriculture Handbook 60, U.S. Dep. of Agriculture, New York (1954) p. 28.

[2] V. A. Kovda, "Arid land irrigation and soil fertility: Problems of salinity, alkalinity and compaction", Ed. E. B. Worthington, "Arid land irrigation in development countries: Environmental problems and effects", Pergamon Press,
Oxford (1977) p. 25.

[3] I. R. Chin, L. Petry, ASTM Spec. Tech. Publ. 1180 (1993) 3.

[4] L. Barzaghi, Cerâmica 29, 164 (1983) 187.

[5] A. G. Verduch, V. S. Solana, Velos, "Florescencias y manchas en obras de ladrilho", Faenza Editrice Ibérica, Castellón (1999).

[6] A. G. Verduch, V. S. Solana, Cerâmica Industrial 5, 5 (2000) 38 .

[7] K. L. Uemoto, "Patologia: Danos causados por eflorescências", PINI, S. Paulo (1988) p. 561.

[8] B. Butterworth, Trans. Brit. Ceram. Soc. 35 (1936) 105.

[9] F. Lipinski, Das Keramische Laboratorium 4, Knapp, Aufl. Dusseldorf (1955).

[10] I. J. C. Ribeiro, Diss. Mestrado, Coord. Pós-grad. Eng. Civil, Univ. Fed. Paraíba, Campina Grande (1996).

[11] S. F. Nascimento, Diss. Mestrado, Coord. Pós-grad. Eng. Quím., Univ. Fed. Paraíba, Campina Grande (1998).

[12] W. L. O. Vale, Diss. Mestrado, Coord. Pós-grad. Eng. Civil, Univ. Fed. Paraíba, Campina Grande (1999).

[13] EMBRAPA, "Manual de métodos de análises de solos, Parte 2 - Análises químicas, Métodos 2.24 a 2.41", Rio de Janeiro (1979).

[14] APHA, "Standard methods for the examination of water and wastewater, Turbidimetric method $\left(\mathrm{SO}_{4}^{2-}\right)$ ", $17^{\text {th }}$ Ed., Washington (1989).

[15] Associação Brasileira de Normas Técnicas, NBR 8947, Rio de Janeiro (1985)

[16] ASTM C 67-92a, "Standard test methods of sampling and testing brick and structural clay tile" (1992).

[17] C. R. Amberg, L. A. Washbur, Am. Ceram. Soc. Bull. 25, 1 (1946) 7.

[18] J. E. Young, J. Am. Ceram. Soc. 40, 7 (1957) 240.

[19] A. N. Williams, R. W. Ford, Trans. J. Brit. Ceram. Soc. 81 (1992) 88.

[20] E. Schmidt, Ziegelind. Die 16, 10 (1963) 343.

[21] B. Butterworth, Trans. Brit. Ceram. Soc. 32 (1933) 270

[22] J. A. Stahmann, Am. Ceram. Soc. Bull. 34, 5 (1955) 138.

[23] Associação Brasileira de Normas Técnicas, NB 1, Rio de Janeiro (1978).

(Rec. 08/09/2004, Rev.13/06/2005, Ac.05/08/2005) 